\title{
An Approach towards Delimitation of Micro-Physiographical Region
}

\author{
Dr. Pawan Kumar Sharma \\ Assistant Professor, \\ Department of General \& Applied Geography \\ Dr. Harisingh Gour Central University, Sagar, M.P.,India. \\ pawansharmageo@gmail.com
}

\begin{abstract}
Recently the new group of regional scientists is focusing on the delimitation of geographical regions at micro-level. The approaches of these regional scientists are empirical, inter-disciplinary, analytical and quantitative. In this present paper the same affords has been made towards delimitation of microphysiographical regions with reference to Jaisalmer district. To create a regional theoretical framework within which practical solutions to regional imbalance can be sought. The purpose of this paper is to trace the development of the concept of micro-level planning region. On the basis of super imposed technique the district has been divided in three physiographical regions which can be used as a research unit to evaluate and categories their socio-economic development level.
\end{abstract}

Keywords: Micro-Physiographical Region, Regional Scientists, Superimposition Method, Acknowledgement: to UGC for providing funds for this research under start up project.

\section{INTRODUCTION}

Now a days, governments and planners have been promoting micro-regionalization has a means of local resource management, improving economic development and sharing basic facilities. In India regions are delineated to improve regional planning and economic development. The natural regionalization is based on criteria like physical landscape, climate, soil type, geology etc. The goals of delimitation of micro-physiographical region at district level are, one is to prepare a plan for micro level regions on the basis of physiographical charactiristics and second is to maximization of local resource utilization. On the basis of the elemental factor of space, a region is a geographic unit with certain limits and bounds. When Geo-socio economic factors are together taken into account at microlevel we get micro-geographical regions. All these small regions are based on the concept of areal homogeneity.

\section{STUdy AREA}

Jaisalmer district is situated in the western part of Rajasthan. It is located between $26^{\circ} 01^{\prime}$ north to $28^{\circ} 02^{\prime}$ north latitudes and $69^{\circ} 29^{\prime}$ east to $72^{\circ} 20^{\prime}$ east longitudes. It covers an area of 38401 square kilometer with population of 672008 persons (census, 2011) and 518 inhabited villages. The district has a population density of 17 inhabitants per square kilometer. Its population growth rate over the decade 2001-2011 was 32.22 percent. The district has a sex ratio of 849 females for every 1000 males, and a literacy rate of 58.04 percent.

The district forms the major part of the 'Marusthali' which is situated in the core of the Great Indian Desert. The district has an undulating terrain mostly covered by brown sand and rocky waste land of desert of 'Thar'. It is sandy, dry and ill watered, unkind to all forms of life. The land slops towards west to the Indus valley and the run of Kutch. The topography is undulating, covered with sand dunes. The district has a desert climate characterized by extreme dryness of large extremes of temperature and erratic rainfall 
MAP1. STUDY AREA

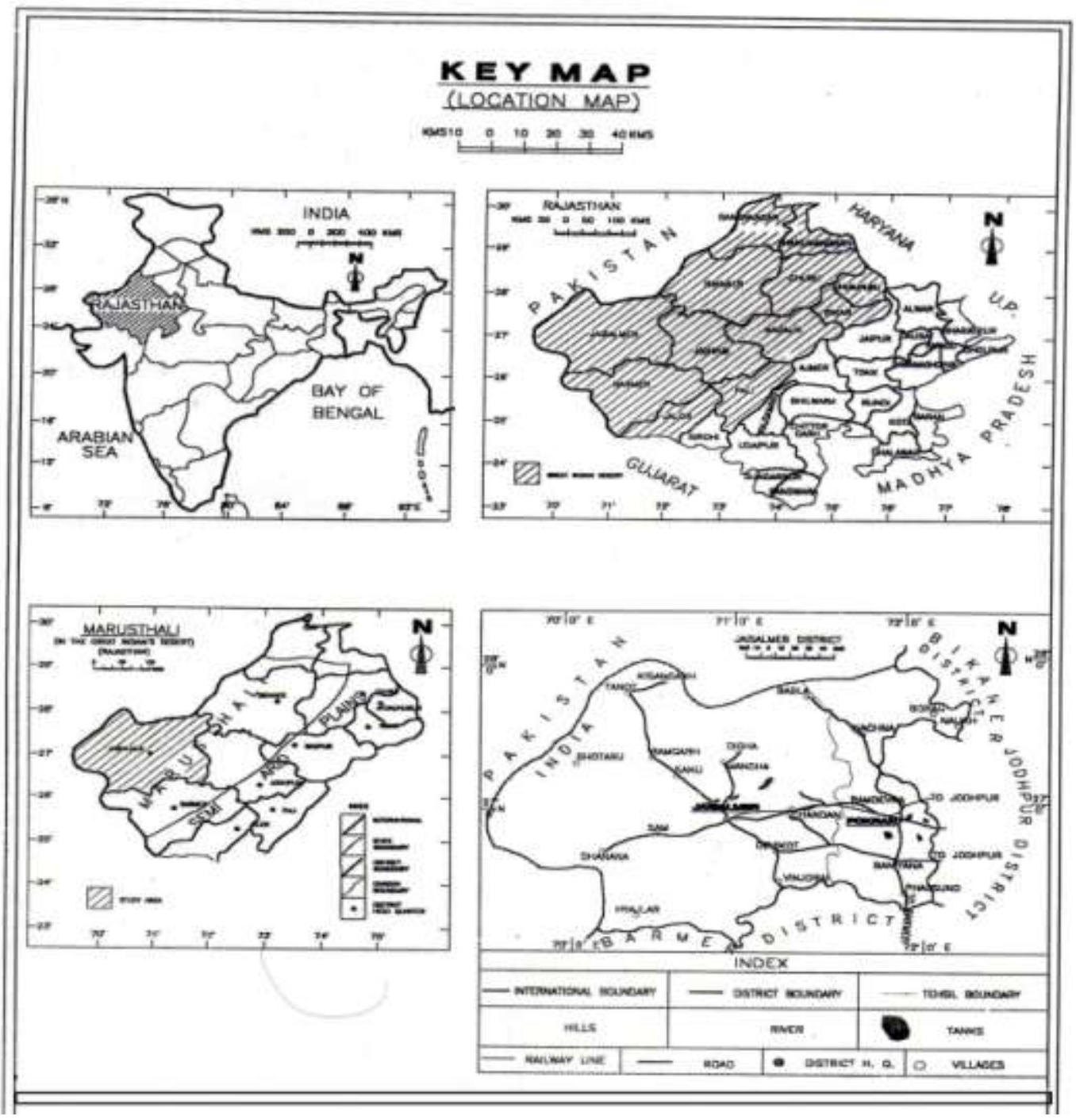

\section{RESULT AND DISCUSSION}

The mapping evaluation and correlation of the data generated in respect of different land attributes within the district led to the recognition of certain patterns of homogeneity in the special distribution of the different geographical factors, and hence, of certain units which have been named as the physiographic units. Each of these has own set of characteristics in respect of geomorphology soil land capability, vegetation, surface and subsurface water, land use etc. and also certain problems and potentials.

The geological formation of the district is unique ancient and complex. The land which now covers the district was submerged under sea up to eocene age. As per the geological survey of India the geological succession in the district is Eocene, Abur, Parihar, Badsar, Baisakhiand and Lathi beds formation. The district exhibits an undulating terrain, mostly covered by blown sand and rocky waste formation. The land covered by the district slopes westward towards the Indus valley and the run of kutch. The sand ridges usually are parallel to the prevailing direction of the wind. In spite of high aridity the district has an immense variability of soil. There are four major soil groups orthids, orthidsorthents, psamments and psamments-orthids found in the district. The average annual rainfall is only $14.17 \mathrm{~cm}$. the rainfall gradually decreases from the southeast to the northwest direction. The vegetation type is included in tropical thorn forest area.

The methodology for delimitation of physical region is the cartographic technique i.e. superimposition of various girdles representing different physical character. The superimposition of relief, forest, slope, soil, drainages and sand dune type and rainfall boundaries shows some uniformity. 
MAP 2. Micro- Level Physiographical Regions

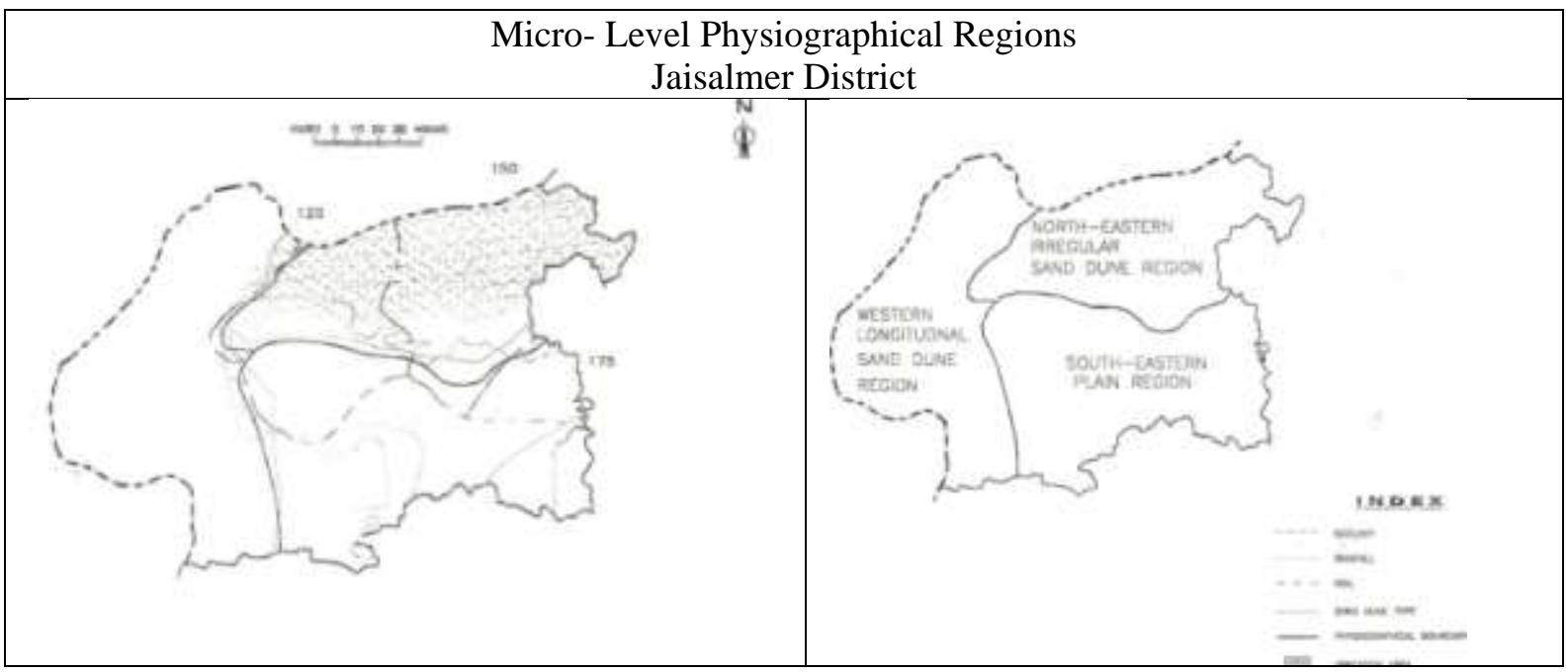

Three major physiographic regions have been recognized and mapped by superimposition technique within the district. Their characteristics and assessment are as follows:

1. Western Longitudinal Sand Dune Region

2. North Eastern Irregular Sand Dune Region

3. South Eastern Plain Region

Table1. Micro-Physiographic Regions of Jaisalmer District

\begin{tabular}{|l|l|l|l|}
\hline $\begin{array}{l}\text { Physiographic } \\
\text { characteristics }\end{array}$ & $\begin{array}{l}\text { Western Longitudinal } \\
\text { Sand Dune Region }\end{array}$ & $\begin{array}{l}\text { North Eastern Irregular } \\
\text { Sand Dune Region }\end{array}$ & South Eastern Plain Region \\
\hline Geographical area & 14856 sq. km. & 9931 sq. km. & 13624 sq. km. \\
\hline $\begin{array}{l}\text { No. of Villages in the } \\
\text { region }\end{array}$ & 124 & 64 & 330 \\
\hline Geology & $\begin{array}{l}\text { Alluvium and blown } \\
\text { sand, Eocene } \\
\text { formations, about beds }\end{array}$ & Alluvian \& blown sand & $\begin{array}{l}\text { Jurasic formation, malanirhyolite, } \\
\text { jalor and siwan aranite, Jaisalamer } \\
\text { limestore }\end{array}$ \\
\hline Soil & $\begin{array}{l}\text { Psamments-orithids, } \\
\text { light yellowish brown } \\
\text { to reddish brown, } \\
\text { coarse textured soil }\end{array}$ & $\begin{array}{l}\text { Orthids and psamments, } \\
\text { sandy loam to loam } \\
\text { gravelly soils }\end{array}$ & $\begin{array}{l}\text { Psamment-orthids and orthids } \\
\text { orthents sandy loam to classy loam } \\
\text { medium texture soil. }\end{array}$ \\
\hline $\begin{array}{l}\text { Drainages on water } \\
\text { resource }\end{array}$ & $\begin{array}{l}\text { Almost no potential } \\
\text { very high potential }\end{array}$ & $\begin{array}{l}\text { Tanks, nadis. Khadeen and } \\
\text { IGNP }\end{array}$ & $\begin{array}{l}\text { Inland drainage channels, kathi } \\
\text { bhadasar and pare war aquifers }\end{array}$ \\
\hline $\begin{array}{l}\text { Rainfall (annual } \\
\text { normal in cm.) }\end{array}$ & 0 to 5 & 12.5 TO 17.5 & 15 to 20 \\
\hline $\begin{array}{l}\text { Population (census } \\
\text { 2011) }\end{array}$ & 68896 & 81364 & 521748 \\
\hline Density & 5 & 8 & 38 \\
\hline
\end{tabular}

\subsection{Western Longitudinal Sand Dune Region}

The Western Longitudinal Sand Dune Region is situated in the north western part of the district along with the international border with Pakistan. Geographically, it is largely a longitudinal and complex sandy desert area with mobile barchans and sand streaks. The geological framework consists a recent to sub recent alluvium sand formation. The regions have a coarse texture soil, which is totally unfertile. There is scarcity of water in the region as is has a very low rainfall $(0$ to $5 \mathrm{~cm}$.) and almost no potential of water resources. Physical condition of the region has unflavored habitation in the area. It has no urban centre and even the villagers are larger size. There are 124 villages the region covering $1486 \mathrm{sq}$. km. area. The population of the region 688968 and density of population is 5 persons per square $\mathrm{km}$ as per census, 2011 . The settlements pattern is generally scattered and the villages are mostly located in the inter dune areas. There is scarcity of water in the region as it is largely dry and sandy region. Therefore the development of transport net work and other facilities is poor in the region. 


\subsection{North Eastern Irregular Sand Dune Region}

The region is located in the northern part of district. The region has a common international boundary with Pakistan in north; in the east it flanked by Bikaner and Jodhpur districts. The greater part of the region is covered by alluvium and blown sand. It is an area of irregular sand dunes with arid land. The average rainfall in the region is 112.5 to $17.5 \mathrm{~cm}$. The rainfall decreases from east to west, while the coefficient of variation increases. The Indira Gandhi Canal is introduced as the life line of the region. At present the mostly the region is getting the irrigation facilities. The region spreads over half of Pokran tehsil and some of Jaisalmer tehsil. It has 64 villages with an area of 9931 sq. $\mathrm{km}$. The region has 81364 people with density of 8 people per square kilometer. Ramgarh is an important village of this region, which is situated on the roadside linking Jaisalmer town with adjoining Mohangarh. Nachna and other important villages. The region has tendency of high economics growth due to availability of irrigational facilities form Indira Gandhi canal.

\subsection{South Eastern Plain Region}

The most important region of the district is South-Eastern Plain region. It lies in the southern east part of the district with common boundary of Jodhpur in the east and Barmer in the South. Geologically, the region comprises Jurassic formation of malani rhyolite, Jalor and Siwan granite and Jaisalmer limestone. The soil is psamment-orthids and orthids-orthenls type of sandy loam to clay loam with medium texture. The normal rainfall of the region is 15 to $20 \mathrm{~cm}$. with yearly variations. Gugri, Sukri and several other seasonal rivers flow through this region during the rainy season and dry up soon thereafter there is dry salt waste water bodies are found in the eastern and northern part of the region. The region spreads over south part of Pokran tehsil and Jaisalmer tehsil, it has 330 villages with an area of 13624 sq. $\mathrm{km}$. The region has population of 521748 with density of 38 people per square kilometer. This region is fairly developed vis-a-vis other region of this district in the field of transport and communication as both rail and road facilities are available in the region. Both the towns of Jaisalmer and Pokran are well connected with other areas. The railway line terminates near Jailasmer town both the national highway no 15 takes a turn toward south and reaches shoe tehsil of Barmer.

\section{Conclusion}

The micro physiographical regionalization is very useful tool in the application of regional policies at bottom level. The Spatial interactions express relations among geographical regions at different hierarchical levels, and they are an important factor in the formation of the geographical organisation of space. This paper provides an empirical analysis of formation of physiographic regions at a lower regional level and at a local level. The final result of the study is a physiographical regionalization map and the delimitation of micro- physiographic regional systems in the Jaisalmer district. The main objective of this paper is to delimit micro- physiographic regions in the Jaisalmer district on the basis of super imposed cartographic technique data derived from the geological survey and meteorological department. The theoretical basis is going to focus on the application of appropriate method delimitating micro-physiographic regions according to spatial distribution of various elements. Finally, before accepting a delineated boundary for a region the socio-economic and demographic conditions should be assessed. This will help in the assessment of the level of development of these regions. Further, through the suitable plan, the integrated area development of the region can be achieved.

\section{REFERENCES}

[1] Annual Report (2012-13) Geological survey of India, Western Region, Jaipur.

[2] Basic statistics, Rajasthan (2011) Directorate of Economics and Statistics Rajasthan, Jaipur

[3] Bhalla, L.R. (2012) Geography of Rajasthan, Kuldeep publication, Ajmer.

[4] Census of India (2011) Districts census handbook, District Jaisalmer Directorate of census operation Rajasthan.

[5] Mishra, R.N., and Sharma, P.K., (2007) Rural growth centres for micro level planning, Ritu Publication, Jaipur.

[6] Nathuranmka, L.N. (2015) Economy of Rajasthan College Book House, Jaipur

[7] Ojha, D.C. (1998) Thar Desert: An overview of Desertification CAZRI, Jodhpur. 
[8] Rajasthan District Gazetteers, Jaisalmer (1973) Directorate, District Gazetteers, Govt. of Rajasthan, Jaipur.

[9] Rao, A.V. Ojha, D.C. and Saxena (Edt.1998) 50 years of Arid Zone research in India (1947 to 1997 an annotated Bibliography, CAZRI Scientific publication Govt. of Rajasthan, Jaipur.

[10] Resource Atlas of Rajasthan (1997) Department of Science and Technology Govt. of Rajasthan, Jaipur.

[11] Sharma, H,S. (1987) Tropical geomorphology: A morphogenetic Study of Rajasthan concept publication, New Delhi.

[12] Statistical outline (2014) District Jaisalmer, Directorate of Economics and Statistics, Rajasthan, Jaipur.

\section{AUTHOR's BIOGRAPHY}

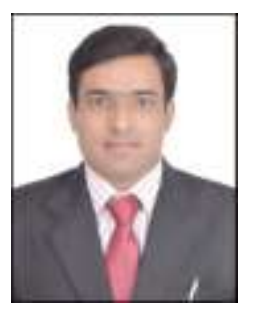

Dr. Pawan kumar Sharma, is position holder of University of Rajasthan in M.A., M.Phil.,(Geography) And Post P.G. Diploma in Population Ecology. He has been awarded by UGC-NET- JRF. Dr. Sharma has got his Ph.D. in Geography in 2005 from the University of Rajasthan. He is member of many national and international academic societies. He has a number of research papers on his credit. He is principal investigator of UGC Start -Up project on the Project title: Micro-level analysis of spatial variation in the level of development in western Rajasthan- A multidimensional approach. Presently he is working as Assistant Professor in Department of General \& Applied Geography, Dr. Harisingh Gour Central University, Sagar, M.P., India. 